\title{
SPATIAL ORGANIZATION OF CYCLACHAENA XANTHIIFOLIA (NUTT.) FRESEN. POPULATIONS ON THE RAILWAY LINE
}

\author{
(C) 2018 \\ Nikitin Nikolay Alexandrovich, postgraduate student of Chair of Biology, Ecology and Methods of Teaching \\ Samara State University of Social Sciences and Education (Samara, Russian Federation)
}

\begin{abstract}
The spatial structure of populations under the conditions of anthropogenic impact is a very important indicator that reflects the behavioral patterns of the species, such as changes in the structure and aggregation of individuals. Quarantine weeds are the object of ecologists' close attention, as these weeds carry the greatest danger to the population, since they most often cause pollinosis and a significant deterioration in the quality of life during seasonal outbreaks of the disease. That is why they should be investigated by methods of analyzing the spatial structure of their populations. Railways are considered to be corridors along which quarantine weeds and other alien and invasive species are able to spread to new territories. Spatial behavior of species, formation of aggregations and large clusters, or a uniform distribution of individuals can reveal a fundamental relationship between the conditions of anthropogenic impact along the right-of-way and the spatial structure of populations. Along the Kinel-Bezenchuk Kuybyshev railroad in the spatial structure of the population of Cyclachaena xanthiifolia (Nutt.) Fresen. there is a group and uniform distribution of individuals. Aggregation of individuals in clusters (group distribution) are found in the places with the highest anthropogenic load.

Keywords: railways; right-of-way; Odum index; Morisita index; spatial structure of populations; populations; absolute population density; rank correlation; Cyclachaena xanthiifolia (Nutt.) Fresen.; anthropogenic factor; aggregation of individuals; spatial heterogeneity; trial sites method; corridors of settlement; invasive species; alien species; quarantine weeds.
\end{abstract}

УДК 595.768.12

DOI 10.24411/2309-4370-2018-14117

Статья поступила в редакцию 16.10 .2018

\section{ФАУНА ЖУКОВ-ЛИСТОЕДОВ (COLEOPTERA, CHRYSOMELIDAE) ИЗОЛИРОВАННЫХ ВОЛЖСКИХ ОСТРОВОВ И МЕХАНИЗМЫ ИХ ВТОРИЧНОГО ЗАСЕЛЕНИЯ}

(C) 2018

Павлов Сергей Иванович, кандидат биологических наук, доцент кафедры биологии, экологии и методики обучения

Яицкий Андрей Степанович, старший преподаватель кафедры биологии, экологии и методики обучения Самарский государственный сочиально-педагогический университет (2. Самара, Российская Федераиия)

Аннотащия. В течение 1974-2016 гг. в природных и лабораторных условиях в Самарской области изучались особенности выживания имаго жуков-листоедов в результате паводкового разлива р. Волги, затопления рекой изолированных островных систем, а также - миграционные процессы насекомых после схода паводковой воды. За 12-летний период полевых исследований 11 специалистов-энтомологов, используя 2 традиционных и 6 авторских методов, на 11 относительно больших волжских островах (3 из которых периодически затапливаются) и 20 крупных, регулярно затапливаемых отмелях и косах собрали коллекцию из 29 видов жуков-хризомелид. Установлено, что фауна листоедов островов по генезису очень близка к фауне сопредельных побережий. Анализируется происхождение и рельеф типичных островов, уровень паводковых вод, продолжительность затопления поймы р. Волги близ Самарской Луки, механизмы выживания жуков путем адаптации их к условиям местообитаний или особенности их миграций, при вторичном заселении островных систем. Установлено, что, кроме активного перелета и автономного плавания на острова, жуки пользуются доступными «плавсредствами» - «плотами» из растительного паводкового шлама, мелкими и достаточно крупными плавающими объектами (от веток и досок до речных судов). Приведены данные по примерным долям участия разных способов передвижения имаго листоедов при их рассредоточении в пространстве. Установлено, что миграции происходят ежегодно, совершенно независимо от успеха перезимовки популяции островных жуков-предшественников.

Ключевые слова: жуки-листоеды; Coleoptera; Chrysomelidae; фауна; фауна жуков; приводные биотопы; островные биотопы; механизмы заселения биотопов; затопляемые острова; незатопляемые острова; песчаные отмели; песчаные косы; механизмы выживания в условиях подтопления; Среднее Поволжье; Самарская область; Волга; Самарская Лука; Жигулёвский заповедник.

\section{Памяти известного российского энтомолога, \\ Юрия Михайловича Зайцева, сотрудника \\ Института проблем экологии и эволюции}

им. А.Н. Севериова РАН (2. Москва), посвящается.

Фенологические особенности климата умеренных широт заключаются в значительной качественной трансформации температурных параметров окружа- ющей среды примерно в равных пределах $-25 \ldots$ $\ldots+25^{\circ} \mathrm{C}$. При низких температурах природа на 5,56 месяцев впадает в состояние глубокого покоя, а 
при высоких - жизнь в течение 6 месяцев расцветает и развивается. Весной выпавший за зиму снег тает, заполняет все понижения рельефа и стекает в реки, провоцируя повышение в них уровня воды. Зимние морозы и весеннее половодье - самые опасные для насекомых, зимующих в «почвенных норах», абиотические факторы среды, нередко «выбраковывающие» большую часть поголовья популяций этих животных.

Цель работы: составить список жуков-листоедов, населяющих острова р. Волги (близ Самарской Луки); выяснить условия выживания насекомых на них, пути и механизмы вторичного заселения изолированных островных систем.

\section{Материал и методика исследований}

Поскольку ситуация и объект исследования весьма специфичны, мы применяли следующие авторские методы: 1) визуальный ручной сбор насекомых с поверхностной пленки спокойной воды по ходу следования медленно плывущей от коренного берега к острову лодки; 2) загребание мелкоячеистым сачком поверхностного слоя воды на «перспективных участках» (где присутствуют какие-либо мелкие плавучие элементы); 3) процеживание поверхностного слоя воды в прибрежной зоне (от 2,5 м) и до самой береговой кромки; 4) ловля мелкоячеистым сачком летящих в воздухе жуков; 5) ручной сбор насекомых на полосе бечевника на удалении в 2 м от уреза во- ды; 6) перемещение на лодке с поднятым на высоту 1,5 м над баком судна светлым тканевым экраномпарусом (при штиле) перпендикулярно береговой линии острова и берега реки; 7) перемещение на лодке со светлым тканевым экраном-парусом навстречу ветру; 8) традиционные методы полевых исследований - кошение сачком и стряхивание жуков с растений, развивающихся на волжских островах, в полог.

Кроме того, нами использованы (предоставленные коллегами для обработки) материалы сборов: С.В. Залящева, С.А. Китанина, В.Н. Макаренкова, С.А. Сачкова и В.Ю. Степанова.

\section{Обсуждение результатов}

Речной остров - участок суши (чаще всего, естественного происхождения), постоянно окруженный со всех сторон водой и расположенный в удаленной (близ зоны судового хода) или в прибрежной части акватории [1].

Острова по их генезису бывают наносные (аккумулятивные, состоящие из легких песчаных или лессовидных пород) и эрозионные (размываемые, состоящие из плотных коренных пород). Кроме того, по степени открытости во время паводка различают острова: незатопляемые и затопляемые (рис. 1). Последние затопляются периодически или регулярно. Затопление обеих групп островов может быть кратковременным или продолжительным [2].

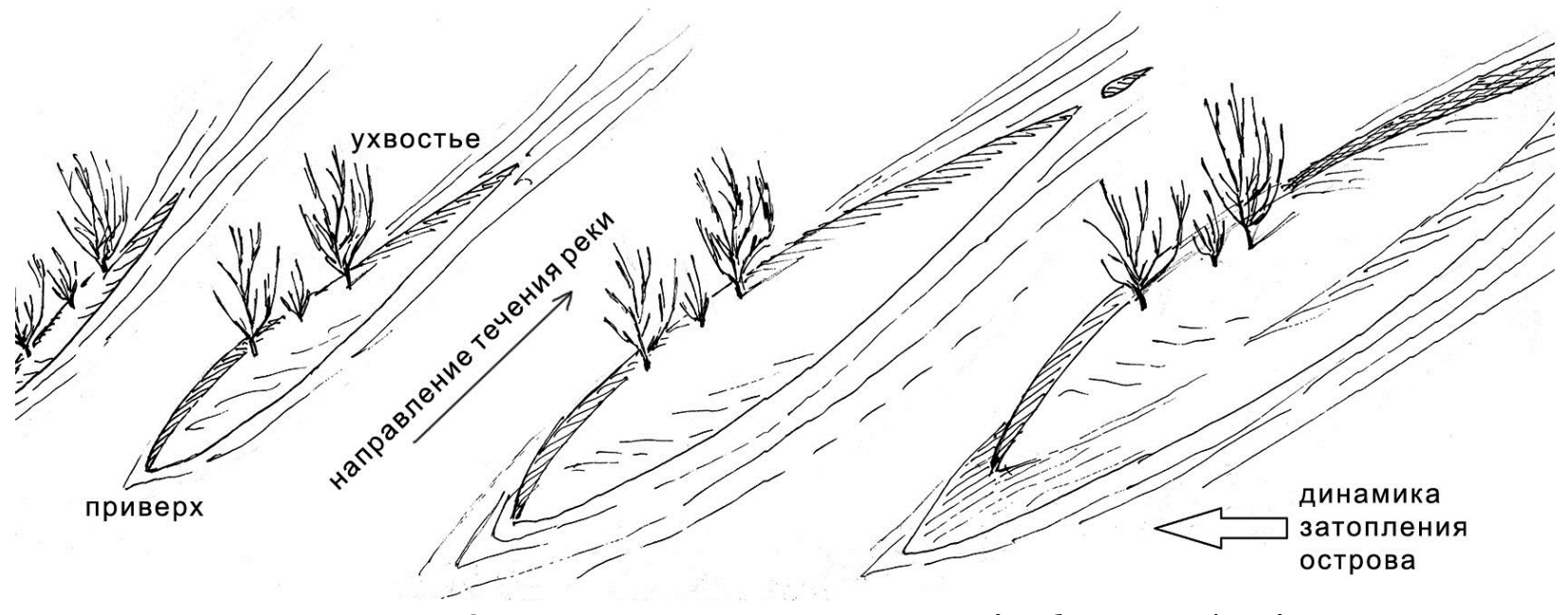

Рисунок 1 - Схема затопления волжского острова (изображены 4 фазы).

Показаны направление течения р. Волги, приверх и ухвостье островов

Bсе островные участки, независимо от их формы в плане, выглядят достаточно стандартно: их приверх (т.е. начало острова, ориентированное навстречу течению) крут и расположен выше ухвостья (конца острова); центральная часть островной суши может быть равной высоте приверха и при этом изгибаться выпуклым куполом (если остров широк) или иметь профиль довольно узкой гривы (если остров вытянут вдоль течения реки). Кроме того, центральный сектор острова может быть несколько приподнят по сравнению с уровнем приверха.

В связи с созданием Волжского гидроэнергетического каскада, и в том числе Жигулевской ГЭС в 1957 г., и нормированным (но не всегда закономерным) поступлением воды в речное русло, естественный ход паводковых процессов в Самарской области значительно изменился, в результате чего приводные биотопы стали испытывать периодическое подтоп- ление в несоответствующее время [3]. Первыми в программу исследования влияния затопления поймы существующих островов и возвышенных участков, часть которых впоследствии стала островами, включились ученые Казанского университета, Казанского филиала АН СССР [4-9] и ряда других организаций $[10 ; 11]$. Поскольку в первую очередь исследовались комплексы наземных насекомых (т.е. самого нижнего яруса затопления), лучше всего оказались изученными фауна жужелиц, стафилинид и чернотелок.

Фауна листоедов анализировалась нами на 11 волжских островах, разбросанных вдоль русла речной излучины (рис. 2), омывающей Самарскую Луку [12; 13]: Шалыга (примерно с 30-х гг. XX в. начал соединяться своим ухвостьем с помощью песчаной косы с о. Серёдышем; с 70-х гг. ХХ в. бывает виден только в межень), Серёдыш (Бахиловский), Серный (Зелененький), Голодный, Поджабный (Рождественский), 
Нижний, Утюжок, Винновский (Вислокаменский), Безымянный, Мордовинский, Охотный (верхний из системы Васильевских островов), кроме того, на 20 крупных косах и отмелях. Все обследованные нами и коллегами острова являются наносными, из

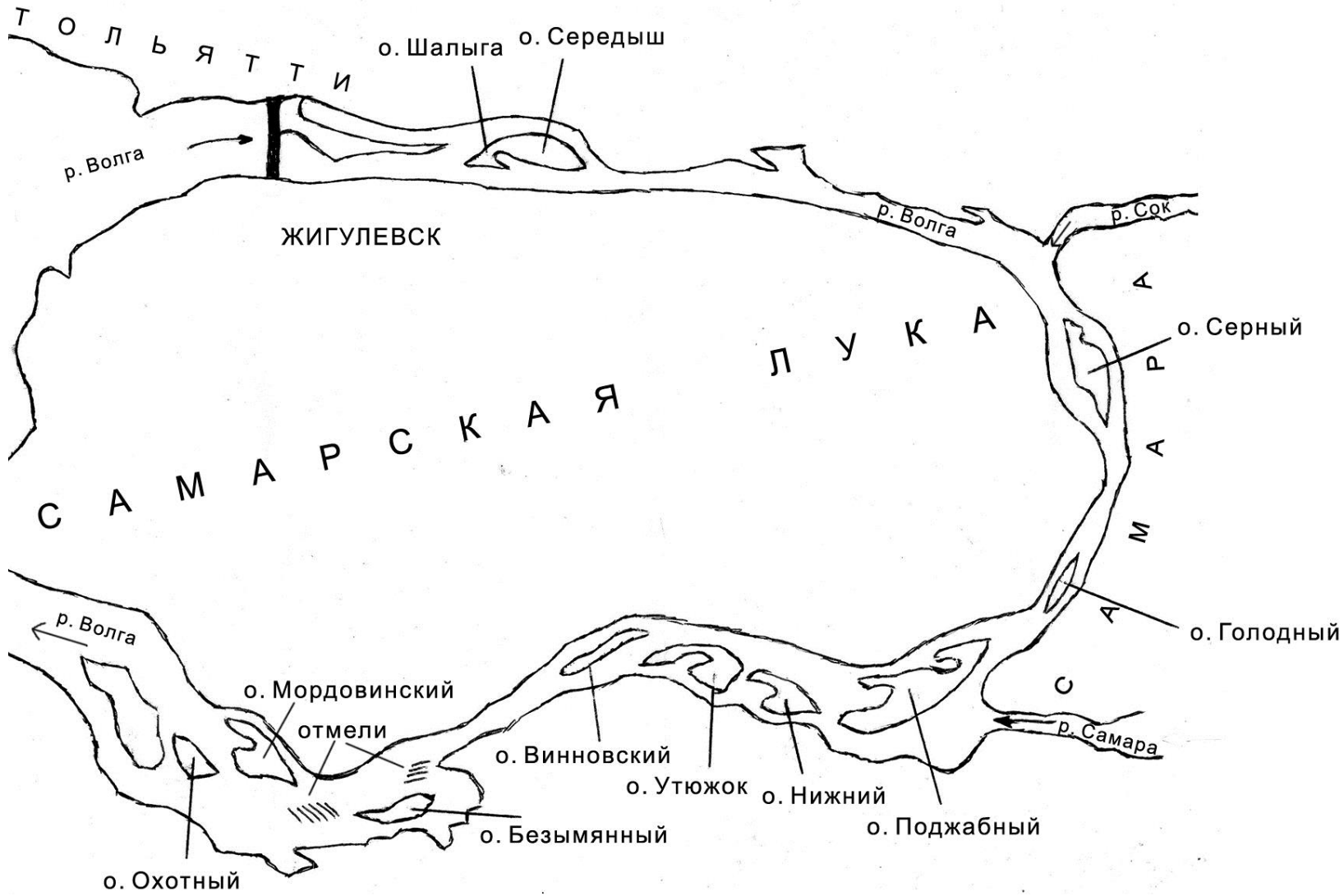

Рисунок 2 - Картосхема расположения модельных островов и песчаных отмелей в абрисе излучины Волги в районе Самарской Луки. Стрелками обозначено направление течения

В итоге за 12 сезонов исследований 11 специалистов собрали коллекцию из 29 видов жуков-хризомелид.

Список листоедов, найденных на островах и в приводньх биотопах р. Волги

1. Donacia dentata Норре. (радужница зубчатая) о. Голодный (сб. В.Н. Макаренкова - 1979 г.); о. Поджабный, побережья ериков, на стрелолисте обыкновенном (сб. С.И. Павлова, 1980 г.).

2. Donacia aquatica L. (радужница водная) - [14]; ЖГЗ, песчаный берег р. Волги, июнь [15].

3. Donacia bicolora Zschach. (радужница двухцветная) - ЖГЗ, о. Середыш, пойменный луг, июль, единично [15]

4. Donacia vulgaris Zschach. (радужница обыкновенная) - ЖГЗ, берег р. Волги, единично [15]; о. Винновский (сб. С.А. Китанина - июнь 1978 г.); о. Серный, прибрежно-водная растительность (сб. С.В. Залящева - 2002 г.).

5. Lilioceris merdigera L. (лилейница луковая) НП «Самарская Лука», о. Мордовинский, 1 экз. (сб. С.А. Сачкова - 22 июля 2004 г.).

6. Labidostomis pallidipennis Gebl. (крупночелюстник палевый) - [14]; ЖГЗ, о. Шалыга, июнь-июль [15].

7. Gonioctena linnaeanus Schrank. (листогрыз Линнея) - ЖГЗ, в зобах и желудках малых зуйков (Деливрон, 1933 г. - цит. по: [15]); 31 мая 1928 г. и 16 августа 1937 г., берег р. Волги, на ивах [14]; ЖГЗ, берег р. Волги, лиственный лес, май, август [15]. них - Нижний, Безымянный и Утюжок, а также все 20 отмелей периодически затапливаются. Минимальное расстояние от берега до островной суши составило 300 м, максимальное - 1200 м. 
17. Phratora vulgatissima L. - известен по сб. 1934 г. А.Р. Деливрона [14; 16]; ЖГЗ, о. Шалыга, июнь [15].

18. Prasocuris phellandrii L. - о. Голодный, травянистая растительность побережий и заболоченных низин (сб. В.Н. Макаренкова - 1979 г.).

19. Neophaedon pyritosus Rossi. - ЖГЗ, о. Шалыга, пойменный луг, июнь, единично [15].

20. Galeruca interrupta Ill. - ЖГЗ, о. Шалыга, известен только по сб. А.Р. Деливрона 11 июня 10 июля 1934 г. [14]

21. Lochmaea capreae L. (козявочка ивовая) о. Нижний, кустарниковые ивы (сб. С.А. Китанина 1978 г.).

22. Galerucella calmariensis L. (козявочка дербенниковая) - [16]; ЖГЗ, о. Шалыга, пойменный луг, май, август, единично [15].

23. Agelastica alni L. (листоед ольховый фиолетовый) - ЖГЗ, о. Серёдыш, берег р. Волги [17]; о-ва Утюжок и Безымянный, заросли низкорослой ольхи (сб. С.И. Павлова - 26 июня 1997 г.).

24. Hippuriphila moderi L. (блошка хвощевая) ЖГЗ, берег р. Волги, на траве рядом с куртинами хвоща [17]; приурочен к регулярно затопляемым участкам речных пойм, предпочитая места с песчаной, слабо заилённой почвой [18].

25. Crepidodera fulvicornis Foudr. (блошка ивовая желтоусая) - [14]; ЖГЗ, о. Шалыга, июнь [15].

26. Crepidodera aurata Marsh. (блошка ивовая золотистая) - $[14 ; 16]$; ЖГЗ, лиственный лес и лесные поляны, редко [15]; окр. прист. «Зеленая роща», заросли молодых узколистных ив (сб. С.И. Павлова 8 июня 1999 г.).

27. Chalcoides lamina Bed. (блошка ивовая блестящая) - ЖГЗ, о. Серёдыш, лес, на иве [17].

28. Altica tamaricis Schrank. (блошка земляная ивовая) - [14]; ЖГЗ, о. Шалыга, июнь-август [15].

29. Longitarsus pellucidus Foudr. (долгопят яркий) - [14]; ЖГЗ, о. Шалыга, май, август [15].

\section{Характеристика паводков}

Относительная отметка уровня воды (многолетняя среднестатистическая местная) в р. Волге в межень составляет 2-3 м [2]; минимальный (обычный, среднестатистический) уровень половодья составляет 2,5-4,0 м; максимальный уровень половодья примерно в 1,5-3,0 раза выше, чем при обычном подъеме уровня воды, т.е. 5,0-8,0 м. Например, - в 1926 г. максимальный уровень составил 16 м, в 1979 г. - 7 м (в этот период только самые высокие участки обычно незатопляемых островов остались свободными от воды) и в 2016 г. $-6,4$ м.

Продолжительность затопления в норме - 57-63 суток (до 20-26 мая), при максимуме - 81-85 суток (до 2-й половины июня).

\section{Механизмы выживания жуков}

По определению академика М.С. Гилярова (цит. по: [3]), для каждого вида биоты в сукцессионном ряду биогеоценоза есть только 2 пути выживания; 1) создание адаптаций, адекватных изменениям среды, вносимым сукцессиями; 2) осуществление миграций в другие условия обитания, отвечающие имеющимся у вида адаптивным способностям.

\section{Адаптаџии жуков}

$\kappa$ условиям местообитаний

К числу важнейших адаптаций жуков-листоедов, населяющих волжские острова, относятся 2 параметра:

1) Зимняя диапауза, выражающаяся в продолжительной приостановке (примерно на 7-8 месяцев, т.е. с начала или середины сентября до начала или середины мая) активного периода жизни, в переходе к состоянию физиологического торможения уровня метаболизма до критически возможного предела, в прекращении роста и размножения организма.

2) Переход из среды воздушно-наземного обитания к пребыванию в приповерхностном слое почвы или песка (на глубине 18-26 см, иногда под пластом листового опада толщиной в 2,5-3,0 cм). Обычно «зимовочные поля» насекомых приурочены к островным гривам (редко затопляемым участкам) и местам концентрации древостоев (где больше листового опада и соответственно несколько «мягче» условия зимовки).

Среди различных деревьев и кустарников, растущих вблизи водоемов, наиболее предпочитаемыми для большинства видов жуков-листоедов являются растения семейства ивовых. Так, например, только на представителях рода Salix обитает 15 , на тополях - 6 видов хризомелид [19]. Средний процент заселения жуками растений ивы достиг (в 1977-1979 и 1986 гг.) $31 \%$, а тополя $-23,5 \%$.

\section{Выживаемость жуков}

в результате подтопления

Для выяснения способности имаго листоедов к выживанию в крайне «жестких условиях затопления» в 2015-2016 гг. нами был проведен эксперимент. В качестве модельного объекта было использовано 600 особей колорадского жука (по 200 - в каждой серии опытов). В 12 кювет, емкостью по 3 л, заполненных пресной водой, температура которой соответствовала каждому сезону года (весна: $+5^{\circ} \mathrm{C}$; лето: $+21^{\circ} \mathrm{C}$; осень: $+13^{\circ} \mathrm{C}$ ), по очереди 5 раз помещали жуков (по 10 особей за 1 подход). В 1-й серии опытов имаго выдерживали в емкости 5 суток; во 2-й серии - 15; в 3-й - 30 и в 4-й - 50 суток. От 50 особей (суммарного числа подопытных жуков в каждой серии опытов за 5 подходов), принятых за 100\%, было рассчитано число выживших жуков (табл. 1).

Таблица 1 - Доля выживших при затоплении имаго колорадского жука (из 50 особей)

\begin{tabular}{|c|c|c|c|}
\hline Время подтопления & Весна & Лето & Осень \\
\hline 5 суток & $14 \%$ & $32 \%$ & $44 \%$ \\
\hline 15 суток & $8 \%$ & $18 \%$ & $20 \%$ \\
\hline 30 суток & $2 \%$ & $0 \%$ & $7 \%$ \\
\hline 50 суток & $0 \%$ & $0 \%$ & $3 \%$ \\
\hline
\end{tabular}

Как видно из таблицы, наиболее устойчивым к действию воды (тем более холодной) является поколение жуков, подготовившихся к зимовке. Весеннее (вышедшее из мест зимовки и растратившее все свои энергетические ресурсы) поколение наиболее ослаблено.

Ранее было установлено, что, плавая в морской воде, колорадские жуки могут оставаться живыми до 20 дней [20].

Е.Н. Поливановой [21] проводилось исследование влияния затопления на яйца вредной черепашки (от- 
ряд Hemiptera). Яйца погружали в воду на 1 или 2 суток [21]. Затопление их при температуре $+25^{\circ} \mathrm{C}$ (оптимальной для развития яиц) приводило к полной гибели эмбрионов на всех этапах их развития. Повреждающее действие затопления яиц в воде, имеющей температуру $+18^{\circ} \mathrm{C}$, оказалось относительно невелико.

Миграции жуков

(вторичное заселение островов)

Вторичное заселение островов наблюдается ежегодно, даже при условии успешной перезимовки населения листоедов островных систем.

Известно 3 пути заселения изолированных островов (перелет жуков; плавание самих имаго в воде или перемещение их на различных плавающих объектах).

1) В безветренную погоду перелет на минимальное расстояние (300 м) от берега занимает у жука 15 20 мин.; перелет на максимальное расстояние $(1200$ м) от берега занимает около 60 мин. (скорее всего, успешная результативность такого перемещения по воздуху может иметь случайный характер). Дальность активного полета колорадского жука составляет около 1 км/сут. [20]. Однако полетом, при расселении с мест зимовки, пользуется $10-12 \%$ жуков. В ежегодном формировании фауны листоедов волжских островов большая роль принадлежит миграционным потокам жуков с подветренных побережий реки. Насекомые, мигрирующие в воздушных струях, были зарегистрированы [22] над морем даже на расстоянии 160 км от ближайшего берега. Чрезвычайно высокая мобильность популяций Hylobius abietis объясняется [23] их тенденцией летать высоко над поверхностью земли, пользуясь попутным ветром. Выяснилось, что только ветер способен помочь в правильной пространственной ориентации, при ночных перелетах насекомых [24]. В большинстве случаев, при достаточно сильных воздушных потоках, исследователи наблюдали прямую или слегка зигзагообразную траекторию перемещения, направление которой совпадало с направлением движения ветра. При слабом и порывистом ветре траектория полета насекомых приобретала все более ступенчатую форму.

При изучении перемещений в пространстве колорадского жука было установлено [20], что массовые заносы вредителя осуществляются именно сильными ветрами или морскими течениями.

2) Листоеды избегают попадания в воду, тем не менее иногда они бывают случайно смыты дождем, набегающими волнами или же сброшены ветром с листьев в воду. Таких фактов нами было зарегистрировано примерно $5 \%$, и если подобное автономное плавание в воде не превышает 1-2-х суток, то около $50 \%$ жуков достигает суши живыми.

3) Перемещение на плавучей основе:

a) Плавание на «плотах из паводкового шлама» (рыхлого настила, состоящего обычно из мелких обломков веток и кусков древесной коры размером не более 20 см). По нашим наблюдениям, на таких часто больших «плавающих островах» древесного мусора путешествуют самые разные виды насекомых, и в том числе до 7 видов жуков-листоедов. Доля перемещающихся подобным образом листоедов составляет примерно $60 \%$ от количества иных способов их расселения в пространстве. При этом, независимо от продолжительности пребывания на «плавучем острове», обычно около $75 \%$ расселяющихся жуков успешно достигает конечной цели путешествия. Нам приходилось встречать скопления хризомелид плотностью до 120 особей/ $\mathrm{M}^{2}$. Однако, по устному сообщению Д.В. Магдеева (2018 г.), методиста зоомузея им. проф. Д.Н. Флорова Самарского государственного социально-педагогического университета, он наблюдал и более значительные (до 350-400 экз./ $\mathrm{M}^{2}$ ) скопления земляных блошек (Halticinae), «путешествующих» на пластах «паводкового шлама».

б) Перемещение на мелких плавающих объектах (щепках, пластиковых баллонах и ветках деревьев) жуки-листоеды, по нашим наблюдениям, предпринимают примерно в $16 \%$ случаев.

в) Перемещение жуков на более или менее крупных плавающих объектах (ящиках, досках, древесных стволах, маломерных или крупных речных судах) зарегистрировано нами примерно в $8 \%$ наблюдаемых случаев.

В то же время, по мнению В.Б. Чернышева, «как диапауза, так и миграции позволяют насекомым избежать неблагоприятных условий во времени и пространстве, приурочить свое развитие к наиболее благоприятному времени года. Однако насекомые платят за эти приспособления энергетическими ресурсами, а следовательно, задержкой развития и снижением плодовитости» [25].

В заключение следует отметить, что:

- во-первых, фауна листоедов островов по генезису очень близка к фауне побережий;

- во-вторых, участки, периодически подвергающиеся затоплению при сходе паводковых вод, довольно быстро вновь заселяются жуками-листоедами;

- в-третьих, независимо от успешности перезимовки жуков, обитающих на островах, последние вновь становятся местом вторичного заселения новых поколений листоедов, мигрирующих с сопредельных участков волжских берегов (причем перемещение жуков осуществляется как по воздуху, так и по поверхности водного зеркала реки);

- в-четвертых, приводимые нами цифры не следует рассматривать как абсолютные (лишенные погрешности) величины, поскольку нам представлялось интересным в первую очередь продемонстрировать ведущие тенденции развития явлений и их реальные векторы.

\section{Список литературы:}

1. Памурзин Ю.П., Карпов Г.В. Словарь по физической географии. М.: Просвещение, 1994. 367 с.

2. Матвеев В.И. Реки и другие водоемы // Природа Куйбышевской области. Куйбышев: ККИ, 1990. C. $100-126$.

3. Мозговой Д.П. Влияние регулирования стока Волги на животный мир поймы Самарской Луки // Проблемы рационального использования и охраны природного комплекса Самарской Луки: межведом. сб., посв. 60-летию ВООП. Куйбышев: КОС ВООП, 1983. C. $105-107$.

4. Садекова Л.Х., Шафигуллина С.М. Сезонный ход численности беспозвоночных островов Куйбышевского водохранилища // Эколого-морфологичес- 
кие особенности животных Среднего Поволжья: межвуз. сб. науч. ст. Казань: КазГПИ, 1984. С. 59-63.

5. Садекова Л.Х., Шафигуллина С.М., Галимова Д.Н., Кашеваров С.Н. Беспозвоночные в условиях островов Куйбышевского водохранилища // Региональные проблемы экологии: тез. докл. конф. экологов Волжско-Камского края. Ч. 1. Казань: Каз. фил. АН CCCP, 1985. C. 76-77.

6. Шафигуллина С.М., Садекова Л.Х., Кашеваров С.Н. Комплексы жужелиц на островах Куйбышевского водохранилища // Региональные проблемы экологии: тез. докл. конф. экологов Волжско-Камского края. Ч. 1. Казань: Каз. фил. АН СССР, 1985. C. $127-128$.

7. Шафигуллина С.М., Садекова Л.Х. Комплексы жужелиц (Coleoptera, Carabidae) на островах Куйбышевского водохранилища // Тр. 9 международ. коллок. по почв. зоол.: тез. докл. М.-Вильнюс: ВЭО, 1985. С. 252.

8. Шафигуллина С.М. Влияние гидрорежима Куйбышевского водохранилища на энтомокомплексы островных экосистем // Успехи энтомологии в СССР: экология и фаунистика, небольш. отряды насекомых: мат-лы 10 съезда ВЭО. Л.: ЗИН РАН, 1993. С. 75-76.

9. Артемьева Т.И., Терентьев А.М. К изучению почвенной фауны островов Куйбышевского водохранилища // Успехи энтомологии в СССР: экология и фаунистика, небольш. отряды насекомых: мат-лы 10 съезда ВЭО. Л.: ЗИН РАН, 1993. С. 5-7.

10. Ларина Н.И., Шляхтин Г.В., Сонин К.А., Беляченко А.В. Влияние гидрологического режима верхней зоны Волгоградского водохранилища на островные популяции мышевидных грызунов // Региональные проблемы экологии: тез. докл. конф. экологов Волжско-Камского края. Ч. 1. Казань: Каз. фил. AH CCCP, 1985. C. 81.

11. Гильденков М.Ю. Сезонная динамика численности прибрежных жесткокрылых в условиях Смоленской области (Coleoptera, Staphylinidae, Carabidae). ДЕП. Смоленск: СГПИ, 1994. 11 с.

12.Самарская область: Альбом топографических карт масштаба 1:200 000 см. Самара: Средневолжское АГП-Роскартография, 2001. Л. 20, 21, 25, 26.

13. Емельянов М.А. Жигулевская «кругосветка». М.-Куйбышев: ККМ, 1935. 144 с.

14. Новодережкин Е.И. Энтомофауна Жигулевского основного участка (предварительный обзор).
Отчет. 1940. 123 с. (Хранится в библиотеке Жигулевского заповедника).

15. Краснобаев Ю.П., Исаев А.Ю., Любвина И.В., Магдеев Д.В., Полякова Г.М. Фауна беспозвоночных Жигулей. IV. Подотряд Polyphaga (Insecta, Coleoptera): Cisidae-Attelabidae // Самарская Лука. Бюллетень. 1994. № 5. C. 127-134.

16. Павлов С.И. Фауна листоедов (Coleoptera, Chrysomelidae) Куйбышевской области // Исследования энтомофауны Среднего Поволжья: Межвуз. сб. науч. ст. Т. 243. Куйбышев: КГПИ, 1980. С. 59-72.

17. Дюжаева И.В., Любвина И.В. Дополнение к энтомофауне Жигулевского заповедника // Биологическое разнообразие заповедных территорий: Оценка, охрана, мониторинг. М.-Самара: Минприроды РФ, 2000. 268-275.

18. Исаев А.Ю. Обзор фауны жуков-листоедов (Coleoptera, Chrysomelidae) Ульяновской области // Самарская Лука. Бюллетень. 2005. № 16. С. 33-77.

19. Павлов С.И. Биоценотическое значение жуков-листоедов (Coleoptera, Chrysomelidae) в приводных биотопах Самарской Луки // Проблемы рационального использования и охраны природного комплекса Самарской Луки: межведом. сб., посвященный 60-летию ВООП. Куйбышев: КОС ВООП, 1983. C. $71-73$.

20. Кохманюк Ф.С. О миграциях имаго колорадского жука (Leptinotarsa decemlineata Say.) // Mexaнизмы поведения животных: мат-лы 3-й Всесоюзн. конф. по повед. животных. Т. 1. М.: Наука, 1983. C. 204.

21. Поливанова Е.Н. Влияние затопления яиц вредной черепашки (Eurygaster intergriceps) на жизнеспособность эмбрионов // Зоологический журнал. 1969. T. 48, № 10. C. 1478-1382.

22. Hardy Alastair C., Cheng L. Studies in the distribution of insects by aerial currents. III. Insect drift over yhe sea // Ecol. Entomol. Vol. 11, № 3. P. 283-290.

23. Solbreck Christer. Insect migration strategies and population dynamics // Contribution in Marine Science. 1985. Vol. 27. Suppl. P. 641-662.

24. Brown E.S. Nocturnal insect flight directionin relation to the wind // Proc. Roy. Entomol. Soc. London, 1970, A45, 1-3. P. 39-43.

25. Чернышев В.Б. Экология насекомых: учебное пособие. М.: МГУ, 1996. 297 с.

\section{FAUNA OF LEAF BEETLES (COLEOPTERA, CHRYSOMELIDAE) OF ISOLATED VOLGA ISLANDS AND MECHANISMS OF THEIR SECONDARY SETTLEMENT} (C) 2018

Pavlov Sergey Ivanovich, candidate of biological sciences, associate professor of Chair of Biology, Ecology and Methods of Teaching

Yaitsky Andrey Stepanovich, senior lecturer of Chair of Biology, Ecology and Methods of Teaching Samara State University of Social Sciences and Education (Samara, Russian Federation)

Abstract. The following paper deals with the study that was carried out during 1974-2016 in natural and laboratory conditions in the Samara Region. The authors studied the features of adults leaf beetles survival as a result of the Volga river flood spill, flooding of the isolated island systems as well as migratory processes of insects. Over a 12year period of field research, 11 entomologists, using 2 traditional and 6 author's methods, have collected 29 species of Chrysomelidae beetles on 11 large Volga Islands (3 of which are periodically flooded) and 20 large, regularly flooded shallows and braids. It is established that the fauna of the Islands' leaf beetles is very close to the fauna of adjacent coasts by genesis. The authors analyze the origin and relief of typical Islands, the level of flood waters, the duration of flooding of the Volga river floodplain near Samarskaya Luka, the mechanisms of survival of beetles by adapting them to the conditions of habitats or features of their migrations, with the secondary settlement of island 
systems. It is established that, in addition to the active flight and autonomous navigation to the Islands, beetles use available «boats» - «rafts from vegetable flood sludge», small and fairly large floating objects (from branches and boards to river vessels). It is established that migrations occur annually, completely regardless of the island beetlespredecessors population wintering success.

Keywords: leaf beetle; Coleoptera; Chrysomelidae; fauna; fauna of beetles; near-water biotopes; island biotopes; mechanisms of settlement biotopes; flood islands; flood-free islands; sandbank; sandbar; coping mechanisms in conditions of flooding; Middle Volga Region; Samara Region; Volga; Samarskaya Luka; Zhiguli Nature Reserve.

\section{СТРУКТУРА ПОПУЛЯЦИЙ MELILOTUS OFFICINALIS (L.) PALL. И TRIFOLIUM PRATENSE L. В ЗОНЕ ШИРОКОЛИСТВЕННЫХ ЛЕСОВ РЕСПУБЛИКИ ТАТАРСТАН}

Прохоренко Нина Борисовна, кандидат биологических наук, доцент кафедры ботаники и физиологии растений

Демина Галина Владимировна, кандидат биологических наук, доцент кафедры ботаники и физиологии растений

Кадырова Луиза Равилевна, кандидат биологических наук, доцент кафедры ботаники и физиологии растений

Казанский (Приволжский) федеральный университет (2. Казань, Российская Федераиия)

Аннотация. В статье обсуждаются результаты исследований структуры популяций клевера лугового и донника лекарственного как ценных медоносных, кормовых и лекарственных растений. В работе проводится сравнительная характеристика популяций данных видов из разных районов зоны широколиственных лесов в пределах Республики Татарстан. Оценка морфологического статута особей в составе популяций проводилась по таким параметрам, как высота побегов, количество побегов на растении, общее число соцветий на растении, сухая биомасса побегов, репродуктивное и фотосинтетическое усилия и др. Плотность, онтогенетическая и виталитетная структура популяций рассматриваются как адаптационные механизмы существования популяций в разных эколого-ценотических условиях. Исследования показали, что популяции донника лекарственного депрессивного типа, в их составе преобладают молодые или зрелые генеративные растения. Средние значения фотосинтетического усилия у донника находятся в пределах от 0,16 до 0,19, а репродуктивного усилия - от 0,12 до 0,19 . Наибольшее репродуктивное усилие отмечается в популяциях, в которых преобладают растениями с низким морфологическим статусом. У клевера лугового формируются популяции разной жизненности (процветающие, равновесные или депрессивные), в ряде условий отмечено наличие растений как генеративного, так и прегенеративного периода, что указывает на успешное семенное возобновление. Средние значения фотосинтетического усилия у клевера лугового в различных условиях произрастания составляют от 0,20 до 0,36, а репродуктивного усилия - от 0,18 до 0,29. Высокие показатели репродуктивного усилия отмечены в популяциях на границе контакта зон широколиственных лесов и лесостепей.

Ключевые слова: донник лекарственный; клевер луговой; репродуктивное усилие; фотосинтетическое усилие; онтогенетическая структура популяций; виталитетная структура популяций; эколого-ценотические условия; зона широколиственных лесов; Республика Татарстан.

\section{Введение}

Для лекарственных растений Республики Татарстан (РТ) приводятся разнообразные сведения об условиях их произрастания, морфологических особенностях, сроках и способах сбора и сушки, особенностях их культивирования $[1 ; 2]$. При этом отсутствует информация, в каких эколого-ценотических условиях происходит наибольшее накопление вторичных метаболитов у различных видов лекарственных растений, а также как способность синтезировать и накапливать эти соединения соотносится с морфологическими особенностями растений и структурой их популяций. Эти данные могут иметь значение при характеристике ресурсов дикорастущих лекарственных растений какого-либо региона.

Цель исследований - дать оценку морфологическому статусу растений и структуре популяций Melilotus officinalis и Trifolium pratense как ценных медоносных, кормовых и лекарственных растений в различных эколого-ценотических условиях на террито- рии зоны широколиственных лесов в пределах Республики Татарстан.

\section{объекты и методика исследований}

Объекты наших исследований - малолетнее растение донник лекарственный и летне-зимнезеленый стержневой травянистый многолетник клевер луговой, которые широко распространены в составе луговых сообществ, а также по сорным местам, железнодорожным насыпям, у дорог, береговым обрывам, окраинам полей, на отмелях и галечниках [3; 4]. В зеленой массе клевера лугового накапливаются эфирное и жирное масла, дубильные вещества, гликозиды, органические кислоты, витамины, в цветках - флавоны и флавонолы, флавоноиды, кумарин, тритерпеновые сапонины, фенолы и др. соединения [5]. В надземных побегах донника лекарственного синтезируется кумарин, эфирные масла, слизи [6; 7].

Анализ структуры популяций исследуемых видов проводился в вегетационный период 2018 г. на территории Лаишевского и Верхнеуслонского районов 